\title{
Serological Specificity of Xanthomonas oryzae, Incitant of Bacterial Blight of Rice
}

\author{
I. C. MAHANTA AND S. K. ADDY \\ Orissa University of Agriculture and Technology, Bhubaneswar, India
}

\begin{abstract}
Agglutination and gel diffusion tests from 12 nomenspecies of the Xanthomonas campestris group, Xanthomonas albilineans, and individual strains of Pseudomonas syringae, Pseudomonas solanacearum, Agrobacterium tumefaciens, Erwinia amylovora, Erwinia stewartii, and Corynebacterium sepedonicum indicated serological distinctiveness of Xanthomonas oryzae, a member of the $X$. campestris group. Heat-stable, species-specific antigens were demonstrated in $X$. oryzae. The serological tests also revealed that most of the Xanthomonas spp. and a few Pseudomonas and Erwinia spp. shared some of the common antigens with $X$. oryzae. $X$. albilineans, $A$. tumefaciens, and $C$. sepedonicum did not share any antigen with $X$. oryzae.
\end{abstract}

Although serology has been utilized in recent years for determining the specific taxonomic relationship among plant pathogens $(1,3,4,6,8)$, no attempt has been made to elucidate the serological relationships between Xanthomonas oryzae, a member of the Xanthomonas campestris group, and other xanthomonads. In a study of segmental homology of deoxyribonucleic acid, it was reported that $X$. oryzae and $X$. translucens $\mathrm{f}$. sp. oryzicola, the streak pathogen of rice, related only at the $10 \%$ level (7). It was also reported that the guanine-plus-cytosine content of the latter was $69 \mathrm{~mol} \%$ as compared to 64.4 $\mathrm{mol} \%$ for the former. Recently $X$. oryzae could be differentiated from $X$. translucens $\mathrm{f}$. sp. oryzicola by its failure to produce certain enzymes, namely, phenylalanine deaminase, tyrosinase, and $\beta$-glucosidase (9). $X$. albilineans also differed from $X$. campestris in certain biochemical properties such as proteolysis of milk, production of $\mathrm{H}_{2} \mathrm{~S}$ from peptone, tolerance of sodium chloride, and acid production from arabinose, trehalose, and cellobiose (2). In the present investigation, both agglutination and gel diffusion techniques were employed to reveal specific antigenic differences between $X$. oryzae and a few selected species of Xanthomonas as well as some bacterial phytopathogens belonging to other genera.

Table 1 lists the strains of various phytopathogenic bacteria used as antigens. Although 12 other isolates of $X$. oryzae and 3 other isolates of $X$. translucens $\mathrm{f}$. sp. oryzicola were also tested, they were not included in Table 1 , as essentially the same results were obtained as with the ones included.

Antiserum against $X$. oryzae (H120) was raised in white rabbits that were immunized by intravenous injections, after adjustment of protein concentration of the antigenic preparation to $675 \mu \mathrm{g} / \mathrm{ml}$ (5).

Agglutination tests were performed at $37^{\circ} \mathrm{C}$ in small conical agglutination tubes using a twofold dilution series of the antiserum.

Gel diffusion tests were performed in $10-\mathrm{cm}$ Pyrex glass petri dishes containing $12 \mathrm{ml}$ of $1 \%$ Ionagar no. 2 (Oxoid) in $0.05 \mathrm{M}$ phosphatebuffered saline at $\mathrm{pH} 7.8$.

The results of the agglutination test in the present study indicate that the highest titer of 5,120 was obtained with the homologous as well as the homologous-heated $\left(100^{\circ} \mathrm{C}\right.$ for $\left.1 \mathrm{~h}\right)$ antigens (Table 1). The antisera to $X$. oryzae reacted to a high titer with $X$. translucens $\mathrm{f}$. sp. oryzicola, X. translucens f. sp. cerealis, and X. malvacearum, indicating closer relationship. It, however, reacted to low titers with other Xanthomonas, Pseudomonas, and Erwinia spp., indicating the sharing of common antigens. $X$. albilineans, Agrobacterium tumefaciens, and Corynebacterium sepedonicum did not react to any titer.

The results of the gel diffusion tests indicated that the homologous antigen produced a greater number of precipitin bands than were produced by heterologous antigens. At least one sharp band showing identity was produced by antigens of $X$. translucens f. sp. oryzicola, X. malvacearum, $X$. oryzae, $X$. vasculorum, $X$. translucens $\mathrm{f}$. sp. cerealis, and $X$. phaseoli. Similarly, another sharp band showing identity was also produced by antigens of $X$. hyacinthi, $X$. campestris, $X$. vesicatoria, $X$. pruni, and $X$. citri. Identity was also demonstrated in one of the bands produced by $X$. juglandis and $X$. citri. $X$. albilineans did not react serologically. 
TABLE 1. Antigenic reactions of some phytopathogenic bacteria against antisera to $X$. oryzae (H120)

\begin{tabular}{|c|c|c|c|}
\hline \multirow{2}{*}{ Antigen } & \multirow{2}{*}{$\begin{array}{l}\text { Agglu- } \\
\text { tinin ti- } \\
\text { ter }\end{array}$} & \multicolumn{2}{|c|}{$\begin{array}{c}\text { No. of precipitin } \\
\text { bands }\end{array}$} \\
\hline & & Sharp & Faint \\
\hline $\begin{array}{l}\text { Xanthomonas oryzae } \\
\text { (H120) }\end{array}$ & $5,120^{a}$ & 4 & 2 \\
\hline X. oryzae $(\mathrm{H} 120)$ (heated) & 5,120 & 1 & 1 \\
\hline$X$.tr.f. sp. oryzicola $(\mathrm{S} 3)^{h}$ & 2,560 & 3 & 0 \\
\hline $\begin{array}{l}X . \text { malvacearum } \\
\text { (XM104) }\end{array}$ & 1,280 & 2 & 0 \\
\hline $\begin{array}{l}X . \text { tr. f. sp. cerealis } \\
(\mathrm{XT} 12)^{b}\end{array}$ & 1,280 & 2 & 1 \\
\hline X. vasculorum (XV106) & 640 & 1 & 1 \\
\hline X. campestris (XC161) & 640 & 4 & 1 \\
\hline X. juglandis (XJ102) & 640 & 2 & 1 \\
\hline X.pruni (XP197) & 640 & 3 & 1 \\
\hline X. vesicatoria (XV173) & 640 & 1 & 2 \\
\hline X. phaseoli (XP205) & 320 & 1 & 1 \\
\hline$X$. citri $(\mathrm{XC} 1)$ & 320 & 3 & 0 \\
\hline X. hyacinthi (XH111) & 160 & 1 & 2 \\
\hline X. albilineans (XA135) & 0 & 0 & 0 \\
\hline $\begin{array}{l}\text { Pseudomonas syringae } \\
\text { (PS200) }\end{array}$ & 320 & 3 & 0 \\
\hline P. solanacearum (PS1) & 160 & 4 & 0 \\
\hline Erwinia stewartii (SS12) & 160 & 3 & 1 \\
\hline E. amylovora (E8) & 80 & 1 & 0 \\
\hline $\begin{array}{l}\text { Agrobacterium tumefa- } \\
\text { ciens (TT136) }\end{array}$ & 0 & 0 & 0 \\
\hline $\begin{array}{l}\text { Corynebacterium sepe- } \\
\text { donicum (CS118) }\end{array}$ & 0 & 0 & 0 \\
\hline
\end{tabular}

"Number represents the denominator of the greatest dilution of the serum clearly showing agglutination.

${ }^{b} X$. tr., X. translucens.

Of the phytopathogens belonging to other genera, some of the bands produced by antigens of Pseudomonas syringae crossed the bands produced by $P$. solanacearum and Erwinia stewar. $t i i$, indicating nonidentity of these antigenic components. Similarly, the band produced by $E$. amylovora also crossed one of the bands produced by $E$. stewartii, again indicating nonidentity. Corynebacterium sepedonicum and Agrobacterium tumefaciens produced no band, indicating their negative serological relationship with $X$. oryzae.

When heated antigens of all the xanthomonads and strains belonging to other genera were tested against antisera to $X$. oryzae, none of them produced any band except the homologous antigen. The heat-stable bands of the homologous antigen were apparently species specific. The process of heating the antigens at $100^{\circ} \mathrm{C}$ for $1 \mathrm{~h}$ has proved particularly advantageous in eliminating the common antigens and demonstrating the precipitation lines produced by heat-stable specific antigens of $X$. oryzae. The heat-labile common antigens are probably involved in the low levels of agglutinin titers obtained with the different species against antisera to $X$. oryzae. The heat-stable nature of the an- tigen is also helpful in distinguishing $X$. oryzae from $X$. translucens $\mathrm{f}$. sp. oryzicola, the streak pathogen in infected rice plants where the latter is commonly encountered as a mixture. This technique, therefore, should be considered as an additional tool in the recently developed method of differentiating $X$. oryzae from $X$. translucens f. sp. oryzicola by the enzymatic tests (9). Our result is also in good agreement with that of Murata and Starr (7) who reported only $10 \%$ DNA homology between $X$. oryzae and $X$. translucens $\mathrm{f}$. sp. oryzicola, reflecting significant genetic divergence.

In the present study, the results of the agglutination as well as the gel diffusion tests further clearly establish that Xanthomonas oryzae is serologically distinct from other Xanthomonas nomenspecies. The high homologous agglutination titer was unequaled by any of the species of Xanthomonas. Similarly the characteristic precipitation band pattern produced in the gel diffusion test by the homologous antigen was not observed with antigens of any other species.

It is also apparent from the results of the foregoing experiments that most of the Xanthomonas spp. as well as a few Pseudomonas and Erwinia spp. share some antigenic components with $X$. oryzae. Therefore, it is quite logical that many of the species of Xanthomonas tested have some common basis to be placed under the genus Xanthomonas.

We wish to express our gratitude to M. P. Starr, R. N. Goodman, A. P. K. Reddy, and S. Devadath for the various bacterial cultures used in the present investigation.

\section{REPRINT REQUESTS}

Address reprint requests to: Dr. S. K. Addy, Department of Plant Pathology, Assam Agricultural University, Jorhat, 785013, Assam, India.

\section{LITERATURE CITED}

1. Charudattan, R., R. E. Stall, and D. L. Batchetor. 1973. Serotypes of Xanthomonas vesicatoria unrelated to its pathotypes. Phytopathology 63:1260-1265.

2. Dye, D. W., and R. A. Lelliott. 1974. Genus Xanthomonas Dowson, p. 243. In R. E. Buchanan and N. E. Gibbous (ed.), Bergey's manual of determinative bacteriology, 8th ed. The Williams \& Wilkins Co. Baltimore.

3. Elrod, R. P., and A. C. Braun. 1947. Serological studies of the genus Xanthomonas. III. The Xanthomonas vasculorum and Xanthomonas phaseoli groups: the intermediate position of Xanthomonas campestris. J. Bacteriol. 54:349-357.

4. Lovrekovich, L., Z. Klement, and W. J. Dowson. 1963. Serological investigations of Pseudomonas syringae and Pseudomonas morsprunorum strains. Phytopathol. Z. 47:19-24.

5. Lowry, O. H., N. J. Rosebrough, A. L. Farr, and R. J. Randall. 1951. Protein measurement with the Folin phenol reagent. J. Biol. Chem. 193:265-275.

6. Lucas, L. T., and R. G. Grogan. 1969. Serological variation and identification of Pseudomonas lachrymans 
and other phytopathogenic Pseudomonas nomenspecies. Phytopathology 59:1908-1912.

7. Murata, N., and M. P. Starr. 1973. A concept of the genus Xanthomonas and its species in the light of segmental homology of deoxyribonucleic acids. Phytopathol. Z. 77:285-323.

8. Otta, J. D., and H. English. 1971. Serology and pathology of Pseudomonas syringae. Phytopathology 61:443-452.
9. Reddy, O. R., and S. H. Ou. 1974. Differentiation of Xanthomonas tranlucens f. sp. oryzicola (Fang et al.) Bradbury, the leaf-streak pathogen, from Xanthomonas oryzae (Uyeda and Ishiyama) Dowson, the blight pathogen of rice, by enzymatic tests. Int. J. Syst. Bacteriol. 24:450-452

10. Sridhar, R., I. W. Buddenhagen, and S. H. Ou. 1973 Presence of lipid bodies in rice leaves and their discoloration during pathogenesis. Experientia 29:959. 